\title{
An overview of analgesics: opioids, tramadol, and tapentadol (Part 2)
}

\section{R van Rensburg*, H Reuter}

Division of Clinical Pharmacology, Department of Medicine, Faculty of Medicine and Health Sciences, Stellenbosch University, Cape Town, South Africa

*Corresponding author, email: rolandmed@gmail.com

\begin{abstract}
Pain can be caused by several mechanisms, and the development of chronic pain (also known as pain chronification) is a complex and often unpredictable process. Opioids, tramadol, and tapentadol provide pharmacological solutions to chronic pain of cancer or non-cancer origins, particularly if central sensitization is present. It may also be indicated for short-term use in acute pain. Despite large studies and meta-analyses of opioids for a variety of pain conditions, the evidence for its clinical effectiveness is still unclear. This is, however, mostly due to significant heterogeneity and bias between studies assessed. The dual analgesic mechanisms of tramadol and tapentadol appear to be effective options for pain relief, with an overall lower incidence of opioidrelated adverse effects. Tapentadol has an analgesic effect comparable to the strong opioids, which appears to be mediated by its greater mu opioid receptor activity and more selective noradrenaline reuptake inhibition. Tramadol produces less analgesia than tapentadol, but it is also associated with reduced opioid-related adverse effects and dependence. The opioids and tramadol may be significantly affected by polymorphisms of CYP2D6, while this effect is lessened with tapentadol.
\end{abstract}

\section{Introduction}

Part 1 of this series discussed NSAIDs, paracetamol, and topical analgesics as the treatment classes of choice for mildto-moderate pain. Moderate-to-severe pain necessitates consideration of multimodal analgesia, and the use of opioids in this setting may be necessary. Part 2 will discuss the opioid class of drugs, as well as drugs that modulate neurotransmitters in addition to opioid-activity (tramadol and tapentadol).

Pain is a complex and distinctive experience. It includes several pathways, involving nociceptive signal generation (transduction) and propagation (transmission), as well as perception and modulation of the nociceptive stimuli. ${ }^{1}$ Pain can been classified according to several approaches, ${ }^{2-4}$ including: acute, chronic, or breakthrough; cancer or non-cancer; nociceptive, neuropathic, or mixed; or according to intensity (mild, moderate, severe). Of these, acute or chronic pain is probably the most commonly assigned classification. Acute and chronic pain were previously seen as separate entities, and delineated according to duration. ${ }^{5,6}$ However, better understanding of the complexity of pain is expanding and questioning this simplified distinction. ${ }^{7}$ Acute pain is seen as an accepted part of life, and serves as a protective function to prevent further injury and promote tissue healing. ${ }^{8}$ Chronic pain was previously defined as lasting more than 6 months, ${ }^{6}$ but has been amended to "pain that lasts beyond the healing of injured tissue and the related inflammatory processes". Chronic pain has a significant impact on quality of life $\mathrm{e}^{9}$ and places a significant burden on both patients and the healthcare sector. ${ }^{10}$ While acute pain was previously seen as distinct from chronic pain, it is now recognised that the transition of acute to chronic pain (termed pain chronification) may actually be a continuum, ${ }^{11}$ and that the underlying mechanisms of pain may be more important than duration in its development. ${ }^{5}$

The mechanisms of pain chronification are not fully understood, and risk factors for its development remain unclear. Proposed mechanisms involve sensitization of nociceptive neurons, and these may be present peripherally and/or centrally. ${ }^{5}$ Peripheral sensitization appears to be induced by persistent stimulation of primary afferent nociceptive neurons leading to neuroplastic changes of the nerves. ${ }^{12}$ These changes confer increased responsiveness ${ }^{6}$ and protracted hypersensitivity of peripheral nociceptive neurons (termed "hyperalgesic priming"), ${ }^{13}$ and constitutes the development of primary hyperalgesia, which leads to steady stimulation of the secondary afferent neurons in the dorsal horn, and may result in secondary hyperalgesia and the development of central sensitization. ${ }^{14}$ This, however, does not fully explain why only some patients with peripheral and/ or central sensitization develop chronic pain. Consequently, pain chronification seems to involve other processes as well, such as changes in pain modulation, neuroplasticity, and pain perception (neuromatrix). ${ }^{5}$

Chronic pain is therefore multifactorial in origin, and involves multiple sites in the nervous system. This is the rationale for multimodal analgesia, ${ }^{15}$ and can be applied to both acute and chronic pain. Pain management was previously approached with substantial reference to the World Health Organization (WHO) analgesic ladder. ${ }^{16}$ The recommended escalation of analgesia by adding increasingly potent opioid drug classes to non-opioids was developed for cancer pain, but has subsequently also been applied to non-cancer pain. While this stepwise approach may provide a good foundation for universal access to analgesia, 


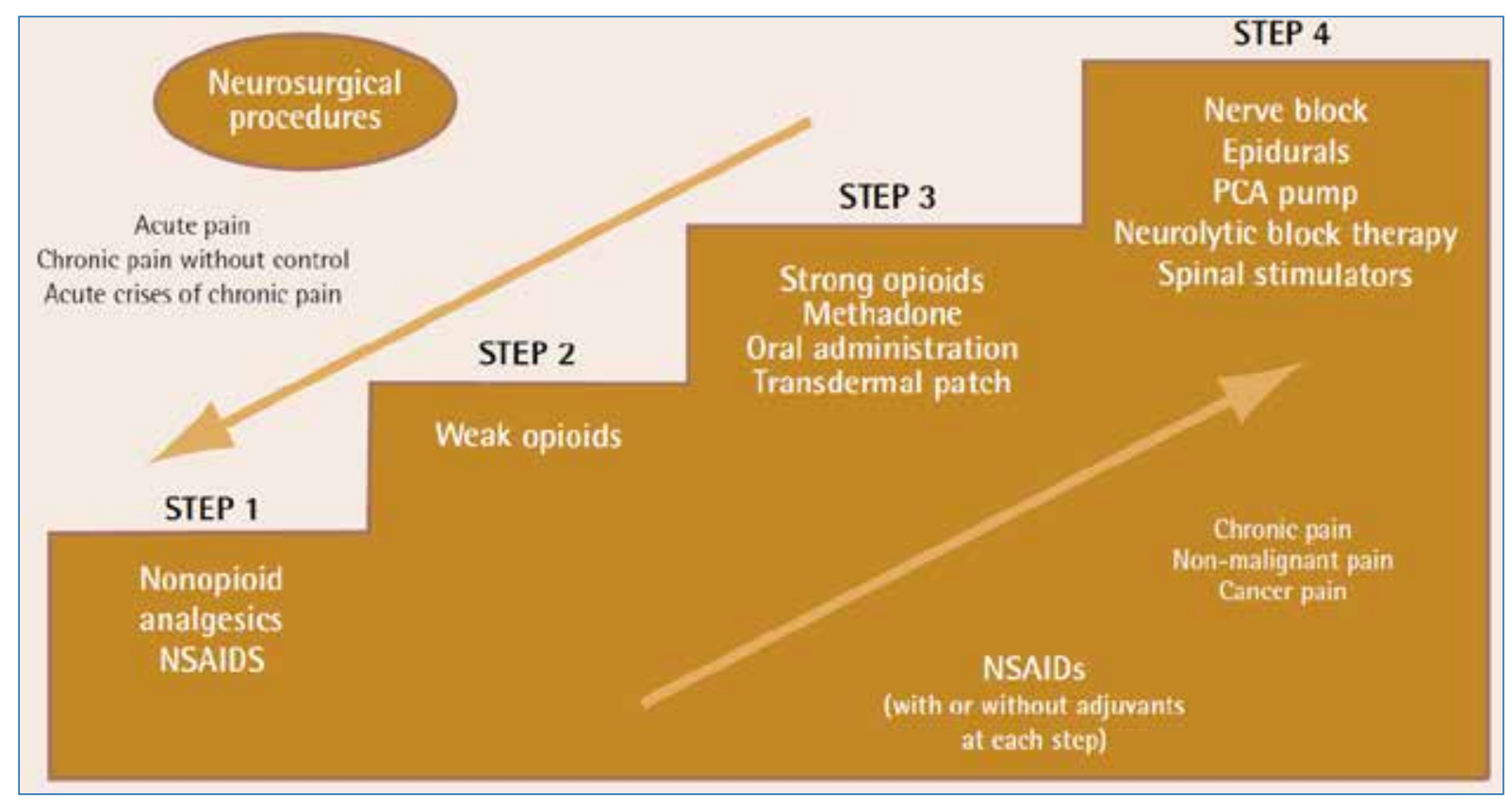

Figure 1: Modified analgesic ladder ${ }^{18}$

NSAIDs - Nonsteroidal anti-inflammatory drugs. PCA - Patient-controlled analgesia

it leaves some gaps, specifically that adequate analgesia is not achieved in many patients, ${ }^{17}$ and that newer analgesic techniques (such as neuraxial procedures) are not incorporated. This in turn may contribute to the development of chronic pain. A new, bidirectional ladder has therefore been proposed to address acute pain adequately, and to optimise the management of chronic pain. ${ }^{18}$ It makes provision for both cancer and noncancer pain, and provides a "start high-step down" approach for acute pain, and a "start low-step up" approach for chronic pain (Figure 1).

\section{Opioids}

\section{Mechanism of action}

The opioids comprise a diverse range of naturally occurring, semi-synthetic or synthetic compounds. These drugs have varying degrees of potency and can act as agonists (e.g. morphine, oxycodone, hydromorphone, codeine), partial agonists (e.g. buprenorphine), or antagonists (e.g. naloxone) at the opioid receptors. ${ }^{19}$ The opioid receptors are classified as mu, kappa, and delta, and revision by the International Union of Pharmacology (IUPHAR) in 2000 expanded the names to include the interchangeable terms MOP (mu opioid peptide), KOP (kappa opioid peptide) and DOP (delta opioid peptide) receptors. ${ }^{20} \mathrm{~A}$ fourth receptor NOP (nociceptin opioid peptide) was later discovered, but its significance is currently not well defined. ${ }^{20}$

The analgesic effects of the opioid agonists are largely mediated by activation of the mu receptors. This activation is also responsible for most of the adverse effects related to opioid use, and includes sedation, respiratory depression, nausea, and vomiting. ${ }^{19}$ Opioid-mediated analgesia originates primarily in the central nervous system, 1,15,19 where it stimulates descending inhibition in the midbrain with the downstream effect of attenuating ascending nociceptive signals in the dorsal horn of the spinal cord (Figure 2). Opioids also stimulate dorsal horn nerve fibres and other peripheral nociceptors directly, further attenuating ascending signals. ${ }^{21}$ The central analgesic effects of opioids also appear to be mediated by modulation of pain perception within the neuromatrix.

Clinical responses to opioids vary and may be related to the type of pain, medical conditions, concomitant drugs, and

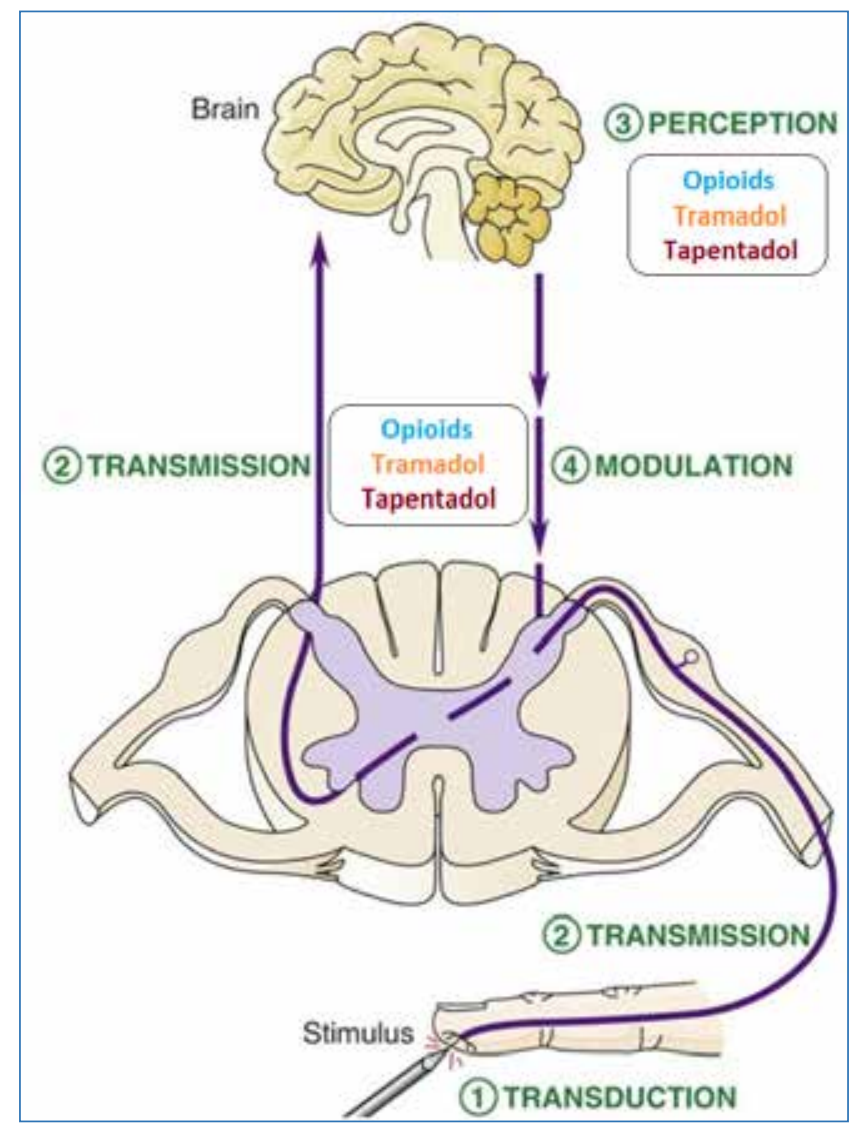

Figure 2: Opioid, tramadol, and tapentadol targets (adapted from Marsh ${ }^{22}$ ) 
patient metabolizer status. ${ }^{23}$ Metabolizer status may account for unexpected responses to opioids, but are difficult to predict as most opioids have complex metabolic pathways with varying degrees of active and inactive metabolites. ${ }^{23} \mathrm{~A}$ classic example is codeine, which exerts the primary analgesic effect via its metabolism to morphine that has a 200 times greater affinity for the mu receptor than codeine itself. ${ }^{24}$ This biotransformation is mediated by cytochrome P450 (CYP) 2D6 enzymes, and the gene encoding these enzymes is highly polymorphic. ${ }^{25}$ Consequently, based on CYP2D6 enzyme activity, patients can be classified as either poor, extensive, or ultrarapid metabolizers. Poor metabolizers are not able to readily convert codeine to morphine, and may therefore not achieve adequate analgesia. ${ }^{24}$ Conversely, ultrarapid metabolizers may generate toxic concentrations of morphine and, following several case reports of this effect, the American Food and Drug Administration (FDA) released a safety announcement restricting its use in children and breastfeeding mothers. ${ }^{26}$ The prevalence of CYP2D6 poor and ultrarapid metabolizers in the general population is estimated to be $5-10 \%$ and $1-2 \%$, respectively. ${ }^{25}$

Pharmacogenetic factors may explain some of the interindividual variation of opioid effects, but even after correcting for these and various other factors, individual responses still vary. Molecular studies have identified different mu receptor subtypes, and have suggested that this variability may be due to differential functional activation by opioids, as well as the receptor subtype localizations in the body. ${ }^{27}$

\section{Place in therapy: Cancer pain}

The management of cancer pain is universally recommended to include a multimodal approach, ${ }^{28}$ encompassing not only multiple pharmacological modalities (if needed), but also including patient education and social structure support. Various international bodies have released guidelines on the principles of cancer pain management, and principles relating to opioids are broadly summarized in Table $1 . .^{29-32}$

Table 1: Summarized recommendations for opioid use in cancer pain management

Patient-specific goals for pain management need to be considered, and the undertreatment of pain prevented.

Persisting or new pain requires comprehensive assessment for possible cause, identification of a pain syndrome, and patient goals.

Oral analgesics are preferred, but pain that requires urgent relief may be managed with parenteral opioids. The use of modified-release opioids for acute pain is discouraged.

In mild to moderate pain not controlled by NSAIDs, a weak oral opioid (codeine or tramadol) may be added according to the WHO analgesic ladder.

In moderate to severe pain strong opioids may be added, but there is no preference between morphine, oxycodone, and hydromorphone.

Switching between different opioids is frequently done in practice for inadequate pain relief or severe adverse effects, but is not supported by strong evidence.

For maintenance analgesia, regular doses of opioids are recommended, with rescue doses as needed. The management of adverse effects (e.g. constipation), and support structures for patients and families are also strongly advocated.

NSAIDs: Nonsteroidal anti-inflammatory drugs. WHO: World Health Organization
The effectiveness and safety of opioids for cancer pain was assessed in a 2017 systematic review of nine previously conducted systematic reviews, and included around 120 studies. ${ }^{33}$ The authors state that the effectiveness of opioids for cancer pain was difficult to interpret due to significant heterogeneity of the studies. However, given extensive clinical experience and the available data, they concluded that for pooled effects of the different opioids, around $95 \%$ of patients with moderate or severe pain who are given opioids - and can tolerate these - should have their pain reduced to mild or no pain within 2 weeks. The review also found that most patients will experience opioid-related adverse effects, and that $10-20 \%$ of these patients will find the adverse effects intolerable, leading to a change in treatment. Of note is that the effectiveness and safety of opioids in these studies were evaluated over a short period of time (weeks). A recent article addressed this lack of evidence of long-term opioid use in cancer pain and highlighted the need for more robust data. ${ }^{34}$ The current opioid epidemic that started in the late $1990 s^{35}$ has highlighted the risk of opioid dependence, and concern for dependence in the cancer population has been expressed. ${ }^{36}$ However, the 2015 American National Survey on Drug Use and Health ${ }^{37}$ surveyed the use of prescription opioids and found that a higher prevalence of prescription opioid use without misuse was present in those with cancer compared to those without cancer ( $93.9 \%$ vs $87.0 \%)$. Cancer patients also had a lower prevalence of opioid misuse without use disorders $(5.3 \%$ vs $10.8 \%)$ and opioid use disorders ( $0.8 \%$ vs $2.2 \%)$ compared to those without cancer.

\section{Place in therapy: Non-cancer pain}

The role of opioids for cancer pain is clearly defined, but the risks and benefits of opioids in acute and chronic non-cancer pain is less well established. Opioids for acute pain are frequently prescribed in the postoperative period, emergency department, and primary care setting. ${ }^{38}$ While opioids can be very effective in these environments, the current opioid epidemic has illuminated how injudicious use of opioids in the acute setting may lead to chronic use and dependence. It is therefore prudent to use opioids selectively for acute pain from the choice of available analgesics. General principles relating to acute opioid prescriptions are to use opioids only for moderate to severe pain at the lowest effective dose for the shortest possible duration, the use of immediate-release formulations of opioids, and to consider multimodal, opioid-sparing management where applicable. $^{32,39}$

A 2018 systematic review and meta-analysis ${ }^{40}$ of 96 randomised controlled trials assessed opioids for chronic non-cancer pain, and included studies of neuropathic pain, nociceptive pain, mixed pain, and central sensitization (defined as pain that is present in the absence of tissue damage). The review found an overall small improvement in pain and physical functioning, but this did not reach clinical significance. An increased risk of vomiting, compared with placebo, was also found. Another systematic review and meta-analysis assessed the evidence of opioids for neuropathic pain..$^{41}$ The findings showed significant efficacy over placebo, although small sample size and short study 
duration likely introduced significant bias. The comparison of opioids to placebo for neuropathic pain also does not reflect best current practice, as other drugs (such as the anti-epileptics and antidepressants) have shown superior efficacy for neuropathic pain. The use of these and other drugs in neuropathic pain, as well as the proposed pathophysiological mechanisms, will be discussed in Part 3 of this series. Further systematic reviews assessing opioids for osteoarthritis of the knee or hip, ${ }^{42}$ or for chronic low-back pain, ${ }^{43}$ found corresponding results: opioids may have a small benefit for pain relief, but low quality studies and significant increases in adverse effects limit its interpretation and significance.

\section{Tramadol}

\section{Mechanism of action}

Tramadol is a centrally acting atypical opioid, as it has both opioid and neurotransmitter reuptake inhibition activity contributing additively to its analgesic effect. ${ }^{44}$ Tramadol is peculiar in that the analgesia produced by mu opioid receptor stimulation is primarily due to an active metabolite (M1) generated by the CYP2D6 enzyme, ${ }^{44-46}$ whereas the parent drug - while having some opioid receptor activity - is largely responsible for neurotransmitter reuptake inhibition. ${ }^{47}$ Tramadol is metabolized to over 20 metabolites, but only M1 as an active metabolite is regarded as significant. ${ }^{48}$

Tramadol is a racemic mixture of (+) tramadol and (-) tramadol, with the $(+)$ enantiomer forming the active M1 metabolite. ${ }^{44}$ The $(+)$ enantiomer is also thought to be primarily responsible for serotonin reuptake inhibition, ${ }^{49}$ while the (-) enantiomer appears to largely mediate noradrenaline reuptake inhibition. ${ }^{50}$ This inhibition of serotonin and noradrenaline reuptake is thought to enhance descending inhibition pathways in the spinal cord ${ }^{44}$ while opioid receptor agonism produces analgesia by mechanisms described earlier (Figure 2). The dual analgesic mechanism of tramadol is further suggested by evidence that naloxone, an opioid antagonist, only partially reverses tramadol's analgesic effect. ${ }^{51}$

\section{Place in therapy}

The potency of parenteral tramadol compared to morphine is in the range of $10 \%$. Oral tramadol has a higher bioavailability than oral morphine, and its potency is estimated to be about $20 \%$ of morphine. ${ }^{52}$ Tramadol appears to be equipotent to codeine at therapeutic doses. . $^{44,52}$ Tramadol does, however, have significant inter-individual variability of efficacy and adverse effects. ${ }^{53}$ This may be related to CYP2D6 polymorphisms, with poor metabolizers at an increased risk for inadequate analgesic response, ${ }^{54}$ and extensive or ultrarapid metabolizers possibly experiencing more adverse effects. ${ }^{53}$ Drugs that are inhibitors or inducers of CYP2D6 may also contribute to the wide variability. ${ }^{55}$ Nausea and dizziness are frequent adverse effects of tramadol, ${ }^{52}$ but its effect on respiratory depression, as well as dependence and abuse potentials, are low compared to morphine. ${ }^{56}$ Of note is that tramadol appears to lower the seizure threshold, and the risk of seizure is increased with concomitant use of other seizure threshold-lowering drugs. ${ }^{57}$ The increase in serotonin induced by tramadol may theoretically cause serotonin syndrome, but this is rarely seen with tramadol as monotherapy, and occurs in practice when other enhancers of serotonin are co-administered. ${ }^{58}$

Tramadol is frequently used to treat acute and chronic pain. For cancer pain management it is part of step 2 of the WHO analgesic ladder. ${ }^{16}$ The efficacy of tramadol for moderate to severe acute pain has been well described, ${ }^{59,60}$ and the addition of non-opioid analgesics (such as paracetamol or an NSAID) appears to potentiate its effects. ${ }^{61,62}$ Several systematic reviews have assessed the efficacy of tramadol in chronic pain conditions including osteoarthritis, ${ }^{63}$ neuropathic pain, ${ }^{64}$ and cancer pain..$^{65}$ A small beneficial effect of tramadol was noted in the analyses of these conditions, but its interpretation and application in clinical practice is limited by low quality evidence, and significant heterogeneity and small sample sizes of the studies.

\section{Tapentadol}

\section{Mechanism of action}

Tapentadol is a new generation atypical opioid that was recently registered in South Africa as a non-racemic, schedule 6 medication. Its design was based on the additive dual mu opioid receptor and neurotransmitter reuptake inhibition mechanism of tramadol, but with greater focus on noradrenaline than serotonin reuptake inhibition. ${ }^{66}$ The rationale for this is based on several studies in animal and human models indicating that increasing noradrenaline concentrations in the spinal cord lead to greater analgesic effects compared to serotonin. ${ }^{66-68}$ In animal models, noradrenaline reuptake inhibition appears to be particularly significant to the attenuation of neuropathic pain. ${ }^{69}$ Tapentadol is an active drug and, contrary to tramadol, its dual activity is not dependant on metabolism to active metabolites for its analgesic effect. ${ }^{55}$ Polymorphisms of CYP2D6, as well as drugs that are inhibitors or inducers of CYP2D6, are therefore not expected to cause significant inter-individual variability. ${ }^{55}$

\section{Place in therapy}

Tapentadol is only available as an oral formulation, and its analgesic potency compared to morphine is estimated to be around $40 \% .^{70}$ This translates to a significant relative increase in the analgesic effect compared to tramadol, but clinically tapentadol is compared to oxycodone, hydromorphone, and morphine. ${ }^{71}$ There is a paucity of data of head-to-head studies comparing tapentadol to tramadol, and this appears to be due to tapentadol's increased analgesic effect leading to comparisons to strong opioid drugs. The potentiated analgesia attained appears to be due to tapentadol's increased mu opioid receptor activity, more potent inhibition of noradrenergic reuptake, and a synergistic - rather than additive - combined effect. ${ }^{72}$ Clinical and post-marketing studies have found that tapentadol has less opioid-related adverse effects compared to the strong opioids, ${ }^{71}$ but the prevalence compared to tramadol still is significantly more. $^{73}$

Tapentadol has shown favourable efficacy to the strong opioids, ${ }^{71,74,75}$ but this mostly relates to chronic or recurrent pain 
(cancer and non-cancer), and may be overstated when subjected to systematic reviews. ${ }^{76,77}$ Tapentadolalso has selected advantages over the strong opioids, including lower risk of dependence and abuse potential, less opioid-related adverse effects, and low risk of pharmacokinetic drug interactions. ${ }^{66,71,74,75,78,79}$

\section{Summary}

Analgesia for moderate-to-severe pain may require the use of opioids, tramadol, or tapentadol. Comprehensive management of chronic pain may need a multimodal approach, as the underlying processes that drive pain chronification appear to be more complex and poorly localized. The evidence for the recommendation of opioids in cancer and non-cancer pain is limited by heterogeneity of studies and frequent adverse effects, but clinical experience indicates that opioids are effective for moderate-to-severe pain. Opioid dependence is a global concern, but current evidence indicates that opioid use for cancer pain is effective without a significant risk of dependence. Tramadol and tapentadol are newer, atypical opioids that are mu receptor agonists as well as neurotransmitter reuptake inhibitors. Tramadol exerts both serotonin and noradrenaline reuptake inhibition in addition to opioid activity, but adverse effects of nausea and dizziness are frequent. Tapentadol has increased analgesic effects compared to tramadol. This appears to be mediated by tapentadol's more potent opioid activity and more selective noradrenergic reuptake inhibition, subsequently making it comparable to the strong opioids. Tapentadol has less opioid-related adverse effects and dependence compared to the strong opioids, but these effects are still significantly more compared to tramadol. For drugs that are metabolized to an active form (such as tramadol or codeine), metabolizer status may significantly impact the effectiveness and safety of these drugs.

\section{References}

1. Answine JF. A Basic Review of Pain Pathways and Analgesia [Internet]. New York; 2018. Available from: https://www.anesthesiologynews.com/Review-Articles/ Article/10-18/A-Basic-Review-of-Pain-Pathways-and-Analgesia/52868

2. Cole BE. Pain Management: Classifying, understanding, and treating pain. Hosp Physician. 2002;23:23-30

3. Kumar KH, Elavarasi P. Definition of pain and classification of pain disorders. J Adv Clin Res Insights [Internet]. 2016 [cited 2019 Feb 11];3:87-90. Available from: http://jcri.net/eJournals/ShowText.aspx?ID=112\&Type=FREE\&TYP=TOP\&I $\mathrm{N}=$ _eJournals/images/JPLOGO.gif\& IID $=12 \&$ Value $=1$ \&isPDF $=Y$ YS

4. Woolf CJ. What is this thing called pain? J Clin Invest [Internet]. 2010 Nov 1 [cited 2019 Feb 11];120(11):3742-4. Available from: http://www.ncbi.nlm.nih.gov/ pubmed/21041955

5. Pergolizzi JV, Raffa RB, Taylor R. Treating Acute Pain in Light of the Chronification of Pain. Pain Manag Nurs [Internet]. 2014 Mar 1 [cited 2019 Feb 8];15(1):38090. Available from: https://www.sciencedirect.com/science/article/pii/ S1524904212000926

6. Merskey H, Bogduk N. IASP Terminology - IASP [Internet]. IASP task force on taxonomy. [cited 2018 Nov 28]. Available from: http://www.iasp-pain.org/ Education/Content.aspx?ItemNumber=1698\#Pain

7. Von Korff M, Dunn KM. Chronic pain reconsidered. Pain [Internet]. 2008 Aug 31 [cited 2019 Feb 11];138(2):267-76. Available from: http://www.ncbi.nlm.nih.gov/ pubmed/18226858

8. Chapman CR, Vierck CJ. The Transition of Acute Postoperative Pain to Chronic Pain: An Integrative Overview of Research on Mechanisms. J Pain [Internet]. 2017 Apr 1 [cited 2019 Feb 8];18(4):359.e1-359.e38. Available from: https://www. sciencedirect.com/science/article/pii/S1526590016303297
9. Kehlet $\mathrm{H}$, Jensen TS, Woolf CJ. Persistent postsurgical pain: risk factors and prevention. Lancet [Internet]. 2006 May 13 [cited 2019 Feb 8];367(9522):161825. Available from: https://www.sciencedirect.com/science/article/pii/ S014067360668700X

10. Goldberg DS, McGee SJ. Pain as a global public health priority. BMC Public Health [Internet]. 2011 Dec 6 [cited 2019 Feb 8];11(1):770. Available from: http:// bmcpublichealth.biomedcentral.com/articles/10.1186/1471-2458-11-770

11. Spacek A. Modern concepts of acute and chronic pain management. Biomed Pharmacother [Internet]. 2006 Aug 1 [cited 2019 Feb 8];60(7):329-35. Available from: https://www.sciencedirect.com/science/article/pii/S0753332206001016

12. Reichling DB, Levine JD. Critical role of nociceptor plasticity in chronic pain Trends Neurosci [Internet]. 2009 Dec [cited 2019 Feb 11];32(12):611-8. Available from: http://www.ncbi.nlm.nih.gov/pubmed/19781793

13. Ferrari LF, Bogen O, Levine JD. Nociceptor subpopulations involved in hyperalgesic priming. Neuroscience [Internet]. 2010 Feb 3 [cited 2019 Feb 11];165(3):896-901. Available from: http://www.ncbi.nlm.nih.gov/ pubmed/19931357

14. Wang CK, Myunghae Hah J, Carroll I. Factors contributing to pain chronicity. Cur Pain Headache Rep [Internet]. 2009 Feb [cited 2019 Feb 11];13(1):7-11. Available from: http://www.ncbi.nlm.nih.gov/pubmed/19126364

15. Argoff $C$. Mechanisms of pain transmission and pharmacologic management. Curr Med Res Opin [Internet]. 2011 Oct 14 [cited 2019 Feb 11];27(10):2019-31. Available from: http://www.tandfonline.com/doi/full/10.1185/03007995.2011.6 14934

16. World Health Organization. WHO's cancer pain ladder for adults [Internet]. WHO. World Health Organization; 2013 [cited 2019 Feb 11]. Available from: https:// www.who.int/cancer/palliative/painladder/en/

17. Azevedo São Leão Ferreira K, Kimura M, Jacobsen Teixeira M. The WHO analgesic ladder for cancer pain control, twenty years of use. How much pain relief does one get from using it? Support Care Cancer [Internet]. 2006 Nov 8 [cited 2019 Feb 11];14(11):1086-93. Available from: http://link.springer.com/10.1007/ s00520-006-0086-x

18. Vargas-Schaffer $\mathrm{G}$. Is the WHO analgesic ladder still valid? Twenty-four years of experience. Can Fam physician [Internet]. 2010 Jun [cited 2019 Feb 13];56(6):514 7. Available from: http://www.ncbi.nlm.nih.gov/pubmed/20547511

19. Pathan H, Williams J. Basic opioid pharmacology: an update. Br J pain [Internet] 2012 Feb [cited 2019 Mar 2];6(1):11-6. Available from: http://www.ncbi.nlm.nih gov/pubmed/26516461

20. Cox BM, Christie MJ, Devi L, Toll L, Traynor JR. Challenges for opioid receptor nomenclature: IUPHAR Review 9. Br J Pharmacol [Internet]. 2015 Jan [cited 2019 Mar 2];172(2):317-23. Available from: http://www.ncbi.nlm.nih.gov/ pubmed/24528283

21. Tegeder I, Meier S, Burian M, Schmidt H, Geisslinger G, Lotsch J. Peripheral opioid analgesia in experimental human pain models. Brain [Internet]. 2003 May 1 [cited 2019 Mar 2];126(5):1092-102. Available from: https://academic.oup.com/ brain/article-lookup/doi/10.1093/brain/awg115

22. Marsh JD. Pain [Internet]. Basicmedical Key. 2016 [cited 2019 Jan 7]. Available from: https://basicmedicalkey.com/pain-3/

23. Smith HS. Opioid metabolism. Mayo Clin Proc [Internet]. 2009 Jul [cited 2019 Mar 2];84(7):613-24. Available from: http://www.ncbi.nlm.nih.gov/pubmed/19567715

24. Thorn CF, Klein TE, Altman RB. Codeine and morphine pathway. Pharmacogenet Genomics [Internet]. 2009 Jul 1 [cited 2019 Mar 2];19(7):556-8. Available from: http://www.ncbi.nlm.nih.gov/pubmed/19512957

25. Dean L. Codeine Therapy and CYP2D6 Genotype [Internet]. Medical Genetics Summaries. National Center for Biotechnology Information (US); 2012 [cited 2019 Mar 2]. Available from: http://www.ncbi.nlm.nih.gov/pubmed/28520350

26. FDA. FDA Drug Safety Communication: FDA restricts use of prescription codeine pain and cough medicines and tramadol pain medicines in children recommends against use in breastfeeding women [Internet]. [cited 2019 Mar 2]. Available from: https://www.fda.gov/downloads/drugs/drugsafety/UCM553814. pdf

27. Pasternak GW. Molecular Biology of Opioid Analgesia. J Pain Symptom Manage [Internet]. 2005 [cited 2019 Mar 2];29(5S):S2-9. Available from: https://www. jpsmjournal.com/article/S0885-3924(05)00037-0/pdf

28. Society guideline links: Cancer pain - UpToDate [Internet]. [cited 2019 Mar 2]. Available from: https://www.uptodate.com/contents/ society-guideline-links-cancer-pain

29. Swarm R, Abernethy AP, Anghelescu DL. Adult Cancer Pain: Clinical Practice Guidelines in Oncology. J Natl Compr Cancer Netw [Internet]. 2010 [cited 
2019 Mar 2];8(9):1046-86. Available from: https://jnccn.org/abstract/journals/ jnccn/8/9/article-p1046.xml

30. Ripamonti Cl, Santini D, Maranzano E, Berti M, Roila F. Management of cancer pain: ESMO Clinical Practice Guidelines. Ann Oncol [Internet]. 2012 Oct 1 [cited 2019 Mar 2];23(suppl 7):vii139-vii154. Available from: https://academic.oup.com/ annonc/article-lookup/doi/10.1093/annonc/mds233

31. Caraceni IA, Brunelli ScD C, Pigni A, Caraceni A, rey Hanks G, Kaasa S, et al. Use of opioid analgesics in the treatment of cancer pain: evidence-based recommendations from the EAPC [Internet]. Vol. 13, Lancet Oncology. 2012 [cited 2019 Mar 2]. Available from: www.thelancet.com/oncology

32. Centers for Disease Control and Prevention. Guideline for Prescribing Opioids for Chronic Pain. J Pain Palliat Care Pharmacother [Internet]. 2016 [cited 2019 Mar 2];30(2):138-40. Available from: https://www.tandfonline.com/action/journallnfo rmation?journalCode=ippc20

33. Wiffen PJ, Wee B, Derry S, Bell RF, Moore RA. Opioids for cancer pain - an overview of Cochrane reviews. Cochrane Database Syst Rev [Internet]. 2017 Jul 6 [cited 2019 Mar 2];7:CD012592. Available from: http://doi.wiley. com/10.1002/14651858.CD012592.pub2

34. Meghani SH, Vapiwala N. Bridging the Critical Divide in Pain Management Guidelines From the CDC, NCCN, and ASCO for Cancer Survivors. JAMA Oncol [Internet]. 2018 Oct 1 [cited 2019 Mar 2];4(10):1323. Available from: http:// oncology.jamanetwork.com/article.aspx?doi=10.1001/jamaoncol.2018.1574

35. Skolnick P. The Opioid Epidemic: Crisis and Solutions. Annu Rev Pharmacol Toxicol [Internet]. 2018 Jan 6 [cited 2019 Mar 2];58(1):143-59. Available from: http://www.annualreviews.org/doi/10.1146/annurev-pharmtox-010617-052534

36. Kata V, Novitch MB, Jones MR, Anyama BO, Helander EM, Kaye AD. Opioid addiction, diversion, and abuse in chronic and cancer pain. Curr Opin Support Palliat Care. 2018;12(2):124-30.

37. Han B, Compton WM, Blanco C, Crane E, Lee J, Jones CM. Prescription Opioid Use, Misuse, and Use Disorders in U.S. Adults: 2015 National Survey on Drug Use and Health. Ann Intern Med [Internet]. 2017 Sep 5 [cited 2019 Mar 2];167(5):293-301. Available from: http://annals.org/

38. Pino CA, Covington M. Prescription of opioids for acute pain in opioid naive patients [Internet]. Fishman S, editor. UpToDate. Waltham, MA: UpToDate; 2019 [cited 2019 Mar 2]. Available from: https://www.uptodate.com/contents/ prescription-of-opioids-for-acute-pain-in-opioid-naive-patients

39. Sundwall DN, Rolfs RT, Johnson E. Utah Clinical Guidelines on Prescribing Opioids for Treatment of Pain [Internet]. Salt Lake City; 2009 [cited 2019 Mar 2]. Available from: http://www.health.utah.gov/prescription/pdf/guidelines/ final.04.09opioidGuidlines.pdf

40. Busse JW, Wang L, Kamaleldin M, Craigie S, Riva JJ, Montoya L, et al. Opioids for Chronic Noncancer Pain. JAMA [Internet]. 2018 Dec 18 [cited 2019 Mar 2];320(23):2448-60. Available from: http://jama.jamanetwork.com/article. aspx?doi=10.1001/jama.2018.18472

41. McNicol ED, Midbari A, Eisenberg E. Opioids for neuropathic pain. Cochrane Database Syst Rev [Internet]. 2013 Aug 29 [cited 2019 Mar 2];8:CD006146. Available from: http://doi.wiley.com/10.1002/14651858.CD006146.pub2

42. da Costa BR, Nüesch E, Kasteler R, Husni E, Welch V, Rutjes AW, et al. Oral or transdermal opioids for osteoarthritis of the knee or hip. Cochrane Database Syst Rev [Internet]. 2014 Sep 17 [cited 2019 Mar 3];9:CD003115. Available from: http://doi.wiley.com/10.1002/14651858.CD003115.pub4

43. Chaparro LE, Furlan AD, Deshpande A, Mailis-Gagnon A, Atlas S, Turk DC. Opioids compared to placebo or other treatments for chronic low-back pain. Cochrane Database Syst Rev [Internet]. 2013 Aug 27 [cited 2019 Mar 2];8:CD004959. Available from: http://doi.wiley.com/10.1002/14651858.CD004959.pub4

44. Grond S, Sablotzki A. Clinical Pharmacology of Tramadol. Clin Pharmacokinet [Internet]. 2004 [cited 2019 Mar 6];43(13):879-923. Available from: http://link. springer.com/10.2165/00003088-200443130-00004

45. Gillen C, Haurand M, Kobelt DJ, Wnendt S. Affinity, potency and efficacy of tramadol and its metabolites at the cloned human $\mu$-opioid receptor. Naunyn Schmiedebergs Arch Pharmacol [Internet]. 2000 Jul 18 [cited 2019 Mar 6];362(2):116-21. Available from: http://link.springer.com/10.1007/ s002100000266

46. Poulsen L, Arendt-Nielsen L, Brøsen K, Sindrup SH. The hypoalgesic effect of tramadol in relation to CYP2D6*. Clin Pharmacol Ther [Internet]. 1996 Dec 1 [cited 2019 Mar 6];60(6):636-44. Available from: http://doi.wiley.com/10.1016/ S0009-9236(96)90211-8

47. Raffa RB, Friderichs E, Reimann W, Shank RP, Codd EE, Vaught JL. Opioid and nonopioid components independently contribute to the mechanism of action of tramadol, an "atypical" opioid analgesic. J Pharmacol Exp Ther. 1992;260(1):275-85.

48. Wu WN, McKown LA, Liao S. Metabolism of the analgesic drug ULTRAM • (tramadol hydrochloride) in humans: API-MS and MS/MS characterization of metabolites. Xenobiotica [Internet]. 2002 Jan 22 [cited 2019 Mar 6];32(5):411-25. Available from: http://www.tandfonline.com/doi/ full/10.1080/00498250110113230

49. Driessen B, Reimann W. Interaction of the central analgesic, tramadol, with the uptake and release of 5-hydroxytryptamine in the rat brain in vitro. $\mathrm{Br}$ J Pharmacol [Internet]. 1992 Jan 1 [cited 2019 Mar 6];105(1):147-51. Available from: http://doi.wiley.com/10.1111/j.1476-5381.1992.tb14226.x

50. Halfenny DM, Callado LF, Hopwood SE, Bamigbade TA, Langford RM, Stamford JA. Effects of tramadol stereoisomers on norepinephrine efflux and uptake in the rat locus coeruleus measured by real time voltammetry. Br J Anaesth [Internet]. 1999 Dec 1 [cited 2019 Mar 6];83(6):909-15. Available from: https://www. sciencedirect.com/science/article/pii/S000709121738159X

51. Desmeules JA, Piguet V, Collart L, Dayer P. Contribution of monoaminergic modulation to the analgesic effect of tramadol. Br J Clin Pharmacol [Internet] 1996 Jan 1 [cited 2019 Mar 7];41(1):7-12. Available from: http://doi.wiley. com/10.1111/j.1365-2125.1996.tb00152.x

52. Expert Committee on Drug Dependence. Tramadol: Update Review Report [Internet]. Geneva; 2014 [cited 2019 Mar 7]. Available from: https://www.who.int/ medicines/areas/quality_safety/6_1_Update.pdf

53. Swen JJ, Nijenhuis M, de Boer A, Grandia L, Maitland-van der Zee AH, Mulder $\mathrm{H}$, et al. Pharmacogenetics: From Bench to Byte- An Update of Guidelines. Clin Pharmacol Ther [Internet]. 2011 May 16 [cited 2019 Mar 7];89(5):662-73. Available from: http://doi.wiley.com/10.1038/clpt.2011.34

54. Stamer UM, Lehnen K, Höthker F, Bayerer B, Wolf $S$, Hoeft A, et al. Impact of CYP2D6 genotype on postoperative tramadol analgesia. Pain [Internet]. 2003 Sep [cited 2019 Mar 7];105(1):231-8. Available from: http:// content.wkhealth.com/linkback/openurl?sid=WKPTLP:landingpage \&an=00006396-200309000-00028

55. Barbosa J, Faria J, Queirós O, Moreira R, Carvalho F, Dinis-Oliveira RJ. Comparative metabolism of tramadol and tapentadol: a toxicological perspective. Drug Metab Rev [Internet]. 2016 Oct 15 [cited 2019 Mar 8];48(4):577-92. Available from: https://www.tandfonline.com/doi/full/10.1080/03602532.2016.1229788

56. Epstein DH, Preston KL, Jasinski DR. Abuse liability, behavioral pharmacology, and physical-dependence potential of opioids in humans and laboratory animals: Lessons from tramadol. Biol Psychol [Internet]. $2006 \mathrm{Jul}$ [cited $2019 \mathrm{Mar}$ 7];73(1):90-9. Available from: http://www.ncbi.nlm.nih.gov/pubmed/16497429

57. Ortho-McNeil Pharmaceuticals. ULTRAM ${ }^{\otimes}$ (tramadol hydrochloride) tablets: Full prescribing information [Internet]. New Jersey; 2003 [cited 2019 Mar 7]. Available from: https://www.accessdata.fda.gov/drugsatfda_docs/ label/2009/020281s032s033lbl.pdf

58. Sansone RA, Sansone LA. Tramadol: seizures, serotonin syndrome, and coadministered antidepressants. Psychiatry (Edgmont) [Internet]. $2009 \mathrm{Apr}$ [cited 2019 Mar 8];6(4):17-21. Available from: http://www.ncbi.nlm.nih.gov/ pubmed/19724727

59. Lehmann KA. Tramadol in acute pain. Drugs [Internet]. 1997 [cited 2019 Mar 7];53(Suppl 2):25-33. Available from: http://www.ncbi.nlm.nih.gov/ pubmed/9190322

60. Scott LJ, Perry CM. Tramadol: a review of its use in perioperative pain. Drugs [Internet]. $2000 \mathrm{Jul}$ [cited 2019 Mar 7];60(1):139-76. Available from: http://www. ncbi.nlm.nih.gov/pubmed/10929933

61. Medve RA, Wang J, Karim R, Johnson RW. Tramadol and Acetaminophen Tablets for Dental Pain. Anesth Prog [Internet]. 2001 [cited 2019 Mar 7];48(3):79-81. Available from: https://www.ncbi.nlm.nih.gov/pmc/articles/PMC2007376/pdf/ anesthprog00015-0015.pdf

62. Edwards JE, McQuay HJ, Moore RA. Combination analgesic efficacy: individual patient data meta-analysis of single-dose oral tramadol plus acetaminophen in acute postoperative pain. J Pain Symptom Manage [Internet]. 2002 Feb 1 [cited 2019 Mar 7];23(2):121-30. Available from: http://www.ncbi.nlm.nih.gov/ pubmed/11844632

63. Cepeda MS, Camargo F, Zea C, Valencia L. Tramadol for osteoarthritis. Cochrane Database Syst Rev [Internet]. 2006 Jul 19 [cited 2019 Mar 7];3:CD005522. Available from: http://doi.wiley.com/10.1002/14651858.CD005522.pub2

64. Duehmke RM, Derry S, Wiffen PJ, Bell RF, Aldington D, Moore RA. Tramadol for neuropathic pain in adults. Cochrane Database Syst Rev [Internet]. 2017 Jun 15 [cited 2019 Mar 7];6:CD003726. Available from: http://doi.wiley. com/10.1002/14651858.CD003726.pub4 
65. Wiffen PJ, Derry S, Moore RA. Tramadol with or without paracetamol (acetaminophen) for cancer pain. Cochrane Database Syst Rev [Internet]. 2017 May [cited 2019 Mar 7];5:CD012508. Available from: http://doi.wiley. com/10.1002/14651858.CD012508.pub2

66. Langford RM, Knaggs $\mathrm{R}$, Farquhar-Smith $\mathrm{P}$, Dickenson AH. Is tapentadol different from classical opioids? A review of the evidence. Br J Pain [Internet]. 2016 Nov 27 [cited 2019 Mar 2];10(4):217-21. Available from: http://journals.sagepub.com/ doi/10.1177/2049463716657363

67. Mochizucki D. Serotonin and noradrenaline reuptake inhibitors in animal models of pain. Hum Psychopharmacol Clin Exp [Internet]. 2004 Oct 1 [cited 2019 Mar 8];19(S1):S15-9. Available from: http://doi.wiley.com/10.1002/hup.620

68. Webster M. Pharmacologic basis for the use of selective norepinephrine reuptake inhibitors for the treatment of neuropathic pain conditions. Ment Heal Clin [Internet]. 2015 Nov 19 [cited 2019 Mar 8];5(6):284-8. Available from: http:// mhc.cpnp.org/doi/10.9740/mhc.2015.11.284

69. Obata H. Analgesic Mechanisms of Antidepressants for Neuropathic Pain. Int J Mol Sci [Internet]. 2017 Nov 21 [cited 2019 Mar 8];18(11):2483. Available from: http://www.ncbi.nlm.nih.gov/pubmed/29160850

70. Tzschentke TM, Christoph T, Kogel B, Schiene K, Hennies H-H, Englberger W, et al. ( )-(1R,2R)-3-(3-Dimethylamino-1-ethyl-2-methyl-propyl)-phenol Hydrochloride (Tapentadol HCl): a Novel -Opioid Receptor Agonist/Norepinephrine Reuptake Inhibitor with Broad-Spectrum Analgesic Properties. J Pharmacol Exp Ther [Internet]. 2007 Jul 23 [cited 2019 Mar 8];323(1):265-76. Available from: http:// www.ncbi.nlm.nih.gov/pubmed/17656655

71. Riemsma R, Forbes C, Harker J, Worthy G, Misso K, Schäfer M, et al. Systematic review of tapentadol in chronic severe pain. Curr Med Res Opin [Internet]. 2011 Oct 12 [cited 2019 Mar 8];27(10):1907-30. Available from: http://www.ncbi.nlm. nih.gov/pubmed/21905968

72. Tzschentke TM, Christoph T, Kögel BY. The Mu-Opioid Receptor Agonist/ Noradrenaline Reuptake Inhibition (MOR-NRI) Concept in Analgesia: The Case of Tapentadol. CNS Drugs [Internet]. 2014 Apr 28 [cited 2019 Mar 8];28(4):319-29. Available from: http://link.springer.com/10.1007/s40263-014-0151-9

73. Tsutaoka BT, Ho RY, Fung SM, Kearney TE. Comparative Toxicity of Tapentadol and Tramadol Utilizing Data Reported to the National Poison Data System. Ann Pharmacother [Internet]. 2015 Dec 14 [cited 2019 Mar 8];49(12):1311-6. Available from: http://www.ncbi.nlm.nih.gov/pubmed/26369569

74. Sánchez del Águila MJ, Schenk M, Kern K-U, Drost T, Steigerwald I. Practical Considerations for the Use of Tapentadol Prolonged Release for the Management of Severe Chronic Pain. Clin Ther [Internet]. 2015 Jan 1 [cited 2019 Mar 8];37(1):94-113. Available from: https://www.sciencedirect.com/science/ article/pii/S0149291814004457?via\%3Dihub

75. Deeks ED. Tapentadol Prolonged Release: A Review in Pain Management. Drugs [Internet]. 2018 Nov 23 [cited 2019 Mar 8];78(17):1805-16. Available from: http:// link.springer.com/10.1007/s40265-018-1007-2

76. Santos J, Alarcão J, Fareleira F, Vaz-Carneiro A, Costa J. Tapentadol for chronic musculoskeletal pain in adults. Cochrane Database Syst Rev [Internet]. 2015 May 27 [cited 2019 Mar 8];5:CD009923. Available from: http://doi.wiley. com/10.1002/14651858.CD009923.pub2

77. Wiffen PJ, Derry S, Naessens K, Bell RF. Oral tapentadol for cancer pain. Cochrane Database Syst Rev [Internet]. 2015 Sep 25 [cited 2019 Mar 8];9:CD011460. Available from: http://doi.wiley.com/10.1002/14651858.CD011460.pub2

78. Stollenwerk A, Sohns M, Heisig F, Elling C, von Zabern D. Review of Post-Marketing Safety Data on Tapentadol, a Centrally Acting Analgesic. Adv Ther [Internet]. 2018 Jan 21 [cited 2019 Mar 8];35(1):12-30. Available from: http:// www.ncbi.nlm.nih.gov/pubmed/29270779

79. Channell JS, Schug S. Toxicity of tapentadol: a systematic review. Pain Manag [Internet]. 2018 Sep 6 [cited 2019 Mar 8];8(5):327-39. Available from: https:// www.futuremedicine.com/doi/10.2217/pmt-2018-0027 